\title{
Tinjauan Etika terhadap Kloning Manusia
}

\author{
Evi Suryanti ${ }^{1,2}$ \\ 1 Pendidikan Biologi, Fakultas Keguruan dan IImu Pendidikan, Universitas Islam Riau, Pekanbaru. \\ 2 Pendidikan IPA, Sekolah Pascasarjana, Universitas Pendidikan Indonesia, Bandung. \\ E-mail: evibio@edu.uir.ac.id
}

\begin{abstract}
Abstrak
Etika merupakan bagian filsafat yang mengkaji prinsip-prinsip moral yang mengatur perilaku seseorang, sehingga dapat juga disebut sebagai filsafat moral. Bahasan etika lebih bersifat baku (normative) dan memberi petunjuk (prescriptive) daripada menggambarkan (descriptive) atau menjelaskan (explanatory). Penentuan objek penelitian dan penerapan pengetahuan perlu berlandaskan prinsip-prinsip etika agar terhindar dari dampak negatif hasil penelitian dan penerapan pengetahuan sains di masyarakat, seperti penurunan kualitas lingkungan dan dehumanisasi. Sejauh ini kasus isu moral terkait sains yang menjadi wacana publik salah satunya adalah kloning manusia. Terdapat dua jenis kloning yang sasaran utamanya manusia, yaitu kloning reproduksi (reproductive cloning) dan kloning terapeutik (therapeutic cloning). Kloning reproduktif bertujuan untuk menghasilkan individu baru, sedangkan pada kloning terapeutik, embrio manusia diklon bukan untuk tujuan reproduksi melainkan untuk pembuatan sel-sel punca (stem cells) untuk mengobati berbagai penyakit manusia. Sel-sel punca adalah sel-sel yang relatif belum terspesialisasi dan dapat memperbanyak diri secara tak terbatas, dan dalam kondisi yang sesuai berdiferensiasi lebih lanjut menjadi satu tipe sel atau lebih. Keberhasilan teknik-teknik kloning manusia menimbulkan isu-isu etis yang menyulut debat panas. Berdasarkan paham teleologi dapat dinyatakan bahwa kloning reproduktif manusia tidak etis ditinjau dari akibat yang dapat ditimbulkan dari teknologi tersebut, seperti mengacaukan silsilah keturunan, rentan terhadap pelanggaran hak hidup yang layak, dan resiko kecacatan.
\end{abstract}

Kata kunci: Kloning manusia, etika sains.

\section{PENDAHULUAN}

Bidang bioteknologi telah memengaruhi kehidupan manusia. Bioteknologi dimaknai sebagai teknik memanipulasi organisme atau komponen organisme untuk menghasilkan produk yang lebih bermanfaat bagi manusia. Sejarah panjang bioteknologi diawali dengan teknik-teknik konvensional seperti pembiakan selektif hewan ternak dan penggunaan mikroorganisme untuk membuat minuman anggur dan keju. Bioteknologi modern mencakup rekayasa genetika (genetic engineering) yang telah berkembang dengan pesatnya sehingga semakin mengembangkan lingkup potensi aplikasi bioteknologi (Campbell \& Reece, 2010). Salah satu aplikasi dari rekayasa genetika adalah teknologi kloning (cloning technology). Kejadian kloning yang spontan banyak terjadi di sekitar kita, misalnya organisme bersel satu berbiak dengan membelah diri dari satu sel menjadi dua sel yang identik dengan sel asalnya, dan proses menumbuhkan tanaman dari potongan bagian suatu tanaman dewasa (Campbell \& Reece, 2010). Adapun yang dimaksud dengan teknologi kloning dalam artikel ini adalah penggunaan teknologi canggih yang melibatkan campur tangan manusia dalam pengontrolan kehidupan yang didukung oleh pesatnya perkembangan ilmu pengetahuan. Teknologi kloning yang diaplikasikan untuk merekayasa pembentukan makhluk hidup, termasuk manusia telah menuai pro dan kontra dari masyarakat Indonesia dan dunia. Keberhasilan kloning pada sedemikian banyak mamalia semakin meningkatkan peluang terjadinya kegiatan untuk mengklon manusia.

Salah satu cabang dalam studi Filsafat IImu adalah etika. Bahasan etika dalam filsafat meliputi prinsip-prinsip moral yang mengatur perilaku seseorang, sehingga dapat juga disebut sebagai filsafat moral. Bahasan etika lebih bersifat baku (normative) dan memberi petunjuk (prescriptive) daripada menggambarkan (descriptive) atau menjelaskan (explanatory). Penentuan objek penelitian dan penerapan pengetahuan perlu berlandaskan prinsip-prinsip etika agar terhindar dari dampak negatif hasil penelitian dan penerapan pengetahuan sains di masyarakat, seperti penurunan kualitas lingkungan dan dehumanisasi (Firman, 2016). Memberikan pertimbangan yang rasional tentang 
dilema-dilema etis yang berhubungan dengan penelitian dan aplikasi sains adalah tugas dari etika sains (Dua dalam Firman, 2016).

Untuk mewujudkan etika dalam aktivitas sains, maka beberapa prinsip etika sains telah dirumuskan, yaitu: (1) Universal; sains berlaku secara umum tanpa memandang ras, warna kulit, kewarganegaraan, dan agama; (2) Komunal; pengetahuan ilmiah harus menjadi milik masyarakat umum, hasil riset harus disebarkan; ilmuwan bebas untuk bertukar informasi di mana pun; ilmuwan harus bertanggungjawab kepada masyarakat ilmuwan akan kredibilitas karya yang dipublikasinya; (3) Tanpa kepentingan; hasil riset ilmiah harus tidak direkayasa untuk kepentingan memeroleh laba (profit), ideologi, dan politik (ilmuwan harus jujur dan obyektif); (4) Skeptis; pernyataan-pernyataan diterima bukan karena kewenangan, dan ilmuwan harus dapat secara bebas mempertanyakan pernyataanpernyataan tersebut serta kebenaran dari pernyataan-pernyataan harus didukung oleh fakta observasi (Firman, 2016).

Lebih lanjut artikel ini akan membahas beberapa aspek terkait topik artikel, seperti pengertian etika dalam filsafat ilmu, sejarah kloning organisme, pengertian dan teknik kloning manusia, dan beberapa persepsi terhadap kloning manusia. Pembahasan aspek-aspek tersebut dimaksudkan untuk memberikan wawasan kepada pembaca sehingga dapat menentukan sikap terhadap pertanyaan penelitian yaitu "Bagaimana tinjauan etika terhadap kloning manusia?"

\section{METODE}

Penelitian ini menggunakan pendekatan kualitatif dengan metode kajian literatur. Menurut Creswell (2012) dan Sugiyono (2016) penelitian kualitatif mengeksplorasi suatu fenomena dan mengembangkan pemahaman yang mendalam terhadap fenomena tersebut. Dalam konteks ini, peneliti meninjau kajian etika terhadap kloning manusia dan beberapa aspek yang terkait dengan topik tersebut. Eksplorasi dilakukan dengan meninjau berbagai literatur hingga diperoleh pemahaman yang mendalam dan dapat dijadikan suatu masukan atau rekomendasi bagi pembaca. Literatur yang digunakan dapat berupa buku atau bab dari buku, artikel jurnal, disertasi, publikasi departemen atau instansi pemerintah, prosiding konferensi atau seminar, dokumen atau laporan, artikel suratkabar, dan sumber dari internet. Teknik analisis data secara deskriptif dengan menganalisis isi literatur terkait dan memberikan interpretasi terhadap temuan eksplorasi.

\section{HASIL DAN PEMBAHASAN}

\section{Etika dalam Filsafat IImu}

Etika adalah salah satu bagian dari kajian aksiologi yang membangun Filsafat IImu. Kata aksiologi berasal dari perkataan axios (Yunani) yang berarti nilai, dan logos yang berarti ilmu atau teori. Jadi, kata aksiologi bermakna 'teori tentang nilai'. Makna 'nilai' di sini adalah sesuatu yang dimiliki manusia untuk memberikan berbagai pertimbangan terhadap apa yang dinilai. Dalam filsafat, aksiologi mengacu kepada permasalahan etika dan estetika. Pengertian sempit dari aksiologi adalah telaah tentang hakikat nilai, yang umumnya ditinjau dari sudut pandang kefilsafatan. Lebih luas, aksiologi memberikan prinsip-prinsip yang harus diperhatikan di dalam menerapkan pengetahuan ke dalam praktek; memuat pemikiran tentang masalah nilai termasuk nilai-nilai tinggi dari Tuhan (nilai agama, nilai moral), nilai estetika/keindahan; dan juga nilai-nilai kehidupan yang bertaraf tinggi (higher values of life) (Susanto, 2014). Menurut Ihsan (2010), karena aksiologi membahas hakikat nilai maka disebut juga dengan 'filsafat nilai'. Selanjutnya Insan (2010) mendefinisikan aksiologi sebagai ilmu pengetahuan yang memaparkan nilai-nilai yang memberi batasan bagi pengembangan ilmu pengetahuan.

Semiawan (2005) menjelaskan etika sebagai kajian tentang hakikat moral dan keputusan/kegiatan menilai (the study of the nature of morality and judgement). Etika sebagai dasar atau standar perilaku manusia, yang kadang-kadang disebut dengan moral. Kegiatan manusia dalam 
menilai (the act of judgement) dibangun berdasarkan toleransi atau ketidakpastian, sehingga tidak ada kejadian yang dapat dijelaskan secara pasti, tanpa toleransi (zero tolerance). Keberadaan segala sesuatu di alam ini adalah hasil dari kesepakatan individu atau kelompok yang dipandang memiliki kewenangan (authority) dalam suatu bidang, yang lantas diikuti oleh masyarakat luas. Terdapat dua bentuk makna etika dalam penggunaannya, yaitu: (1) etika sebagai kumpulan pengetahuan mengenai penilaian terhadap perbuatan-perbuatan manusia, dan (2) etika sebagai suatu predikat atau sebutan yang dipakai untuk membedakan hal atau perbuatan manusia. Objek formal etika mencakup kriteriakriteria atau norma-norma kesusilaan manusia dan menelaah baik buruknya tingkah laku manusia.

Menurut Suhartono (2008), kata etika berakar dari bahasa Yunani ethikos atau ethos yang bermakna adat atau kebiasaan. Kata etika kemudian berkembang menjadi setara (equivalent) dengan kata moralitas. Kata etika dan moralitas secara implisit menyiratkan adanya hubungan dengan kegiatan praktis yaitu perilaku. Perilaku etis berkaitan dengan tingkah laku atau perbuatan yang bernilai baik dan benar, sehingga etika sering disebut dengan 'filsafat moral' atau 'filsafat tingkah laku'. Tradisi filsafat membagi etika menjadi dua, yaitu etika normatif dan meta-etika (etika kreatif?). Etika normatif membahas pengukuran perbuatan baik dan benar berdasarkan norma-norma tradisional/konvensional sebagai penuntun atau petunjuk perilaku. Sementara itu, meta-etika cenderung bersifat filosofis, yaitu perbuatan baik dan benar diukur berdasarkan analisis kritis logis. Kedua kriteria ini bisa dijadikan pedoman 'bagaimana seharusnya manusia bertingkah laku' (how men ought to act in general). Hanya menurut dasar hak (right) dan kewajiban (duty) yang 'seharusnya', maka suatu perilaku dapat dinilai baik dan benar. Dengan kata lain, etika menilai kebaikan suatu tingkah laku menurut norma yang berlaku (dasar adat kebiasaan) dan tujuan yang dapat diterima oleh akal. Jika dihubungkan dengan ilmu pengetahuan, maka kebenaran ilmiah dengan nilai kemanfaatannya harus menjadi tolok ukur perilaku. Suatu perilaku dinilai baik apabila memiliki nilai kebenaran ilmiah dan bermanfaat bagi tercapainya tujuan hidup manusia dalam masyarakatnya.

Tinjauan dari sisi filsafat sangat menentukan suatu nilai itu objektif atau subjektif. Nilai itu objektif jika tidak tergantung pada subjek atau kesadaran yang menilai, sedangkan nilai subjektif selalu memerhatikan berbagai pandangan yang dimiliki akal budi manusia, seperti perasaan dan intelektualitas, sehingga hasil penilaian subjektif akan mengarah kepada suka atau tidak suka, senang atau tidak senang. Munculnya nilai objektif berdasarkan pandangan dalam filsafat tentang objektivisme, di mana tolok ukur suatu gagasan berada pada objeknya yang benar-benar ada (Susanto, 2014). Jalaluddin (2013) menyatakan bahwa nilai adalah realitas yang abstrak yang berfungsi sebagai daya pendorong atau prinsip-prinsip yang menjadi pedoman dalam hidup. Nilai penting dalam kehidupan seseorang, bahkan ada orang yang lebih siap mengorbankan hidup ketimbang mengorbankan nilai. Pola tingkah laku, pola berpikir, dan sikap-sikap pribadi atau kelompok merupakan tiga realitas yang dapat digunakan untuk melacak nilai yang dimiliki seseorang atau kelompok.

Sejalan dengan asas moral dalam pemilihan objek penelaahan ilmiah, maka penggunaan pengetahuan ilmiah mempunyai asas moral tertentu pula. Sejatinya ilmu harus dimanfaatkan untuk kemaslahatan manusia dan sebagai sarana dalam meningkatkan taraf hidup manusia dengan memerhatikan kodrat dan martabat manusia serta kelestarian/keseimbangan alam (Ihsan, 2010).

\section{Sejarah Kloning Organisme (Organism Cloning)}

Seiring dengan kemajuan teknologi DNA, para ilmuwan telah mengembangkan dan memperbaiki metode-metode untuk mengklon organisme multiseluler utuh dari satu sel. Penggunaan teknologi kloning dapat menghasilkan satu atau lebih organisme yang secara genetis identik dengan 'induk' yang mendonorkan sel tunggal. Ini sering disebut dengan 'kloning organisme' (organismal cloning). Kata klon bermula dari kata Yunani klon, yang berarti 'ranting'. Percobaan pertama untuk mengklon tumbuhan dan hewan telah dilakukan lebih dari 50 tahun lalu dalam sejumlah percobaan yang dirancang untuk menjawab pertanyaan-pertanyaan biologi yang mendasar yang intinya adalah "apakah kloning organisme mungkin dilakukan?" (Campbell \& Reece, 2010).

Keberhasilan kloning tumbuhan utuh dari sel-sel tunggal yang telah terdiferensiasi dicapai pada 
tahun 1950-an oleh F.C. Steward dan mahasiswa-mahasiswanya di Cornell University yang meneliti tumbuhan wortel. Mereka menemukan bahwa sel-sel terdiferensiasi yang diambil dari akar wortel dan diinkubasi dalam medium kultur dapat tumbuh menjadi tumbuhan wortel dewasa normal, yang identik secara genetis dengan tumbuhan induk (Campbell \& Reece, 2010).

Dalam kloning hewan, para peneliti dahulu harus menggunakan pendekatan yang berbeda untuk menjawab pertanyaan "apakah sel-sel hewan yang telah terdiferensiasi bisa menghasilkan organisme (hewan) utuh?" Pendekatannya adalah dengan cara membuang nukleus (inti sel) sel telur yang belum maupun sudah terfertilisasi dan menggantinya dengan nukleus dari sel yang sudah terdiferensiasi. Prosedur ini disebut dengan transplantasi nukleus (nucleus transplantation). Jika nukleus dari sel donor yang telah terdiferensiasi tetap menunjukkan kemampuan genetik penuh, maka seharusnya nukleus itu mampu mengarahkan perkembangan sel penerima menjadi semua jaringan dan organ organisme. Percobaan-percobaan semacam itu dilakukan terhadap katak oleh Robert Brigg dan Thomas King pada 1950-an dan John Gurdon pada 1970-an (Campbell \& Reece, 2010).

Selain mengklon katak, para peneliti juga telah mampu mengklon mamalia dengan menggunakan nukleus atau sel dari berbagai embrio awal. Namun, saat itu belum diketahui apakah nukleus dari sel yang telah terdiferensiasi penuh dapat diprogram-ulang agar bisa bertindak sebagai nukleus donor. Akan tetapi, pada 1997, sejumlah peneliti Skotlandia menyita perhatian media ketika mengumumkan kelahiran Dolly, anak domba yang diklon dari domba dewasa melalui transplantasi nukleus dari sel yang telah terdiferensiasi. Analisis yang dilakukan setelahnya menunjukkan bahwa DNA kromosom Dolly memang identik dengan induk yang mendonorkan nukleus. Pada 2003, saat berusia 6 tahun, Dolly menderita komplikasi akibat penyakit paru-paru yang biasanya hanya terjadi pada domba yang jauh lebih dewasa, dan akhirnya dieutanasia. Kematian prematur Dolly dan juga artritis (radang paru-paru) yang dideritanya, menimbulkan spekulasi bahwa sel-selnya tidak sesehat sel domba yang normal (Campbell \& Reece, 2010).

Pada tahun 1997 itu para peneliti telah mengklon banyak mamalia lain, antara lain mencit, kucing, sapi, kuda, bagal, babi, dan anjing. Pada sebagian besar kerja kloning tersebut, tujuannya adalah pembuatan individu baru. Prosedur ini dikenal sebagai kloning reproduktif (reproductive cloning). Dari hasil-hasil percobaan itu, ditemukan bahwa hewan hasil klon dari jenis (species) yang sama tidak selalu terlihat atau berperilaku identik, misalnya ditemukan pada sapi dan kucing. Selain itu, jika kita perhatikan manusia yang kembar identik, yang merupakan 'klon' yang terjadi secara alamiah, sifatnya selalu agak berbeda. Jelaslah, pengaruh lingkungan dan fenomena acak pada kromosom dapat memainkan peranan yang signifikan selama fase perkembangan. Selanjutnya, dalam sebagian besar penelitian transplantasi nukleus ini, hanya ada sebagian kecil embrio hasil klon yang berkembang secara normal sampai lahir. Seperti Dolly, banyak hewan hasil klon tersebut yang menunjukkan kecacatan. Misalnya mencit hasil klon rentan obesitas, pneumonia, gagal hati, dan kematian prematur. Para ilmuwan menyatakan bahwa hewan klon yang tampaknya normal sekali pun kemungkinan memiliki cacat yang samar (Campbell \& Reece, 2010).

\section{Kloning Manusia (Human Cloning)}

Keberhasilan kloning pada sedemikian banyak mamalia telah meningkatkan spekulasi tentang kloning manusia (reproductive cloning). Ilmuwan di beberapa laboratorium di dunia telah berhasil melakukan langkah-langkah pertama dari upaya ini. Pendekatan paling umum yang dilakukan dalam teknologi kloning ini adalah nucleus dari sel manusia (yang diinginkan) yang telah terdiferensiasi ditransplantasikan ke dalam sel telur ter-enukleasi (inti selnya telah dibuang) yang belum dibuahi, dan sel telur dirangsang untuk membelah. Jika inti sel dari sel donor yang telah terdiferensiasi tetap menunjukkan kemampuan genetik penuh, maka seharusnya inti sel itu mampu mengarahkan perkembangan sel penerima menjadi semua jaringan dan organ dari organisme. Akan tetapi, kemampuan inti sel melakukan hal itu berkurang seiring semakin terdiferensiasinya sel donor, mungkin karena perubahan-perubahan yang terjadi dalam inti sel. Pada 2001, kelompok penelitian di Massachusetts mengamati beberapa pembelahan sel awal dalam percobaan semacam itu. Beberapa 
tahun kemudian, para peneliti Korea Selatan melaporkan keberhasilan mengklon embrio manusia hingga tahap awal yang disebut tahap blastosit (Campbell \& Reece, 2010).

Selain kloning reproduktif (reproductive cloning) yang bertujuan untuk menghasilkan individu baru, dikenal juga kloning terapeutik (theurapeutic cloning). Dalam kloning terapeutik, embrio manusia diklon bukan untuk tujuan reproduksi, melainkan untuk pembuatan sel-sel punca (stem cells) untuk mengobati berbagai penyakit manusia. Sel punca adalah sel yang relatif belum terspesialisasi dan dapat memperbanyak diri secara tak terbatas, dan dalam kondisi yang sesuai berdiferensiasi lebih lanjut menjadi satu tipe sel atau lebih. Dengan demikian, sel-sel punca mampu memperbarui populasinya sendiri sekaligus menghasilkan sel-sel yang menempuh jalur-jalur diferensiasi yang spesifik. Sel-sel punca dapat diisolasi dari embrio awal pada tahapan yang disebut tahap blastula atau tahap blastosit pada embrio manusia. Sel-sel punca yang diambil dari embrio ini disebut sel-sel punca embrio (embryonic stem cells) (Campbell \& Reece, 2010).

Hasil-hasil penelitian terhadap sel-sel punca embrionik menunjukkan potensi besar untuk aplikasi medis seperti menyediakan sel-sel untuk perbaikan organ yang rusak atau berpenyakit, misalnya selsel pankreas penghasil insulin bagi pengidap diabetes, atau jenis-jenis sel otak tertentu bagi penderita Parkinson atau penyakit Huntington. Sel-sel punca embrionik sangat menjanjikan untuk aplikasi medis karena bersifat pluripoten (pluripotent), yaitu mampu berdiferensiasi menjadi berbagai macam tipe sel yang berbeda. Sejauh ini satu-satunya cara untuk memperoleh sel punca embrionik adalah dengan memanen dari embrio manusia, sehingga menimbulkan isu-isu etis dan politis (Campbell \& Reece, 2010).

Sel-sel punca embrionik diperoleh dari embrio yang didonorkan oleh pasien-pasien yang menjalani terapi kesuburan atau dari kultur sel jangka panjang yang awalnya dibuat dengan sel-sel yang diisolasi dari embrio donor. Jika para ilmuwan mampu mengklon embrio manusia pada tahap blastosit, klon tersebut mungkin bisa digunakan sebagai sumber sel-sel punca embrionik di masa depan. Melalui nukleus donor dari penderita penyakit tertentu, mungkin mampu menghasilkan sel-sel punca embrionik untuk pengobatan yang cocok dengan pasien sehingga dapat diterima oleh sistem kekebalan tubuhnya (Campbell \& Reece, 2010).

\section{Persepsi Masyarakat terhadap Kloning Manusia}

Pada saat maraknya isu kloning manusia sekitar tahun 1997, berbagai reaksi masyarakat Indonesia terungkap dalam sebuah seminar yang diselenggarakan oleh KONPHALINDO di Jakarta pada Juni 1997. Dr. dr. Theodorus Immanuel Setiawan dalam makalahnya tentang "Perkembangan Teknologi Kloning dan Kaitannya dengan Etika Kedokteran" mengemukakan bahwa tujuan kloning manusia terutama untuk mengabadikan atau melahirkan manusia unggul baik secara fisik dan mental. Namun, Setiawan memperingatkan sisi negatif teknologi kloning pada manusia bisa menjadi berbahaya, jika jatuh ke tangan pihak-pihak yang tidak bertanggungjawab terhadap aspek kemanusiaan dan lingkungan (Lani dalam Widayanti dan Krishnayanti, 2003).

Etika kedokteran tidak menghalangi seseorang yang ingin mengkloning dirinya. Akan tetapi seorang dokter harus menyediakan informasi yang adekuat dan pertimbangan yang tidak mengikat kepada pasiennya agar dapat mengambil keputusan yang bijaksana bagi dirinya. Bagaimana dengan perlindungan terhadap manusia hasil kloning yang kelak akan lahir? Etika biomedik dengan tegas menyatakan bahwa manusia hasil kloning adalah sama kedudukan dan martabatnya dengan manusia hasil reproduksi seksual. Karena itu, tindakan mengeksploitasi manusia hasil kloning untuk kepentingan manusia lain harus dikecam. Apakah kloning pada manusia perlu dilakukan? Setiawan mengajak peserta seminar meninjau kembali aspek positif dan negatif dari kloning (Lani dalam Widayanti dan Krishnayanti, 2003).

Hari Hartiko, Ph.D. dalam makalahnya "Kloning pada Tumbuhan, Hewan dan Manusia dan Kaitannya dengan Etika Lingkungan" mempertanyakan landasan yuridis jika kloning manusia diperkenankan. la mencemaskan jika penggandaan manusia secara massal yang semula diharapkan dapat meningkatkan kualitas manusia justru mengubah perilaku suatu bangsa menjadi tidak terkendali. 
Royalti yang sangat mungkin dituntut oleh individu pemilik gen yang akan diklon juga memerlukan landasan hukum yang kuat. Sementara itu ketidakpastian juga menguak dari aspek moral dan perikemanusiaan jika kloning diterapkan pada manusia. Pemusnahan embrio manusia yang tidak jadi diklon (dalam penelitian kloning manusia di AS) oleh banyak orang tidak hanya dikecam sebagai kekejian, tetapi juga tidak bermoral. Di AS, keinginan seseorang untuk membuat klon dirinya dijamin oleh hak asasi manusia. Lalu bagaimana dengan hak asasi manusia-manusia hasil kloning, karena mungkin saja seseorang tidak akan senang jika ia lahir sebagai hasil rekayasa? Apakah cukup adil dengan mengatakan bahwa kloning manusia dilakukan atas dasar perikemanusiaan, misalnya untuk membantu pasangan suami istri yang tidak bisa mempunyai keturunan dengan cara alamiah, atau untuk kepentingan penelitian? (Lani dalam Widayanti dan Krishnayanti, 2003). Di samping itu, Kusmaryanto (2001) berpendapat bahwa individu hasil kloning diangggap sebagai kopian dari individu asal yang dianggap sebagai induknya karena memiliki sifat yang sama dengan induknya. Akibatnya terjadi kekacauan status apakah klon tersebut adalah 'anak' atau merupakan 'kembaran' dari individu asalnya.

Semiawan, dkk. (1988) berpendapat bahwa teknologi kloning manusia memiliki aspek postif, yaitu: a) dapat mempertahankan eksistensi manusia-manusia "super" dalam berbagai bidang keahlian dan keilmuan yang juga dilengkapi dengan sifat-sifat luhur terhadap kesejahteraan sesama manusia, b) munculnya kembali makhluk-makhluk yang sudah musnah atau baru saja mati. Sedangkan aspek negatifnya adalah: akan muncul manusia-manusia yang seragam, dan keseragaman bukanlah ciri makhluk hidup yang tinggi tingkatannya, b) terdapat keseragaman daya tahan tubuh pada manusia hasil kloning yang dapat terancam punah jika berjangkit wabah penyakit. Namun, sampai saat ini teknologi kloning belum berhasil seratus persen. Sebanyak 277 kali percobaan dilakukan pada kasus Dolly, 30 kali percobaan di antaranya yang inti sel-nya berkembang, dan hanya satu saja yang berhasil disuntikkan ke rahim domba betina. Dapat dibayangkan jika penelitian itu dilakukan terhadap seorang perempuan, berapa kali mereka harus melahirkan anak-anak yang tidak normal akibat kesalahan prosedur? (Daulay, 2012).

Pada tanggal 28 Juni-3 Juli 1997, ulama sedunia bertemu di Makkah al-Mukarramah dalam kegiatan seminar bertemakan "Islamic Fiqh Academy" dengan topik utama meninjau kedudukan dan hukum kloning dalam syariat Islam. Seminar tersebut dihadiri oleh 125 orang meliputi para fuqaha dan pakar bioetik dari penjuru dunia. Secara aklamasi diputuskan bahwa kloning terhadap hewan dan tumbuhan diperbolehkan, sedangkan kloning terhadap manusia diharamkan (Daulay, 2012). Selanjutnya larangan tentang kloning manusia dikeluarkan oleh jawatan kuasa Fatwa Majelis Kebangsaan Malaysia pada 11 Maret 2002 melalui keputusan mudzakarah yang ke 51 yang menetapkan bahwa: (1) Untuk tujuan apapun kloning manusia adalah haram, karena bertentangan dengan fitrah kejadian manusia, sebagaimana yang ditentukan oleh Allah SWT, dan (2) Penggunaan stem cells dengan tujuan medis diperbolehkan selama tidak bertentangan dengan hukum syara' (Sudjana, 2015).

\section{Tinjauan Etika terhadap Kloning Manusia}

Pemerintah dan badan-badan regulasi di seluruh dunia berupaya untuk menemukan cara memfasilitasi penggunaan bioteknologi dalam aspek kehidupan manusia, dan juga harus mempertimbangkan implikasi etis dari bioteknologi. Pertimbangan etis serta kekhawatiran tentang potensi bahaya lingkungan dan kesehatan, mungkin akan memperlambat sejumlah aplikasi bioteknologi. Biasanya terlalu banyak regulasi akan menghambat penelitian dasar dan potensi-potensi manfaatnya. Akan tetapi, kekuatan yang dimiliki oleh teknologi DNA dan rekayasa genetika ini mengharuskan adanya upaya untuk membuat regulasi tersebut dengan rendah hati dan berhati-hati (Campbell \& Reece, 2010).

Bila Terdapat dua pandangan etika terhadap penerapan kloning, yaitu deontologi dan teleologi. Paham deontologi menitikberatkan penilaian etis-tidaknya suatu perbuatan kepada perbuatan itu sendiri. Immanuel Kant adalah tokoh utama dalam paham ini yang terkenal dengan teori categorical 
imperative-nya. Menurut Kant, perbuatan yang terlarang secara umum (universal), apa pun alasannya tidak boleh dilakukan. Misalnya, mencuri, berbohong, atau membunuh tidak boleh dilakukan meskipun tujuannya untuk menyelamatkan orang lain, karena perbuatan-perbuatan tersebut secara umum dianggap tidak baik atau jahat. Bukan berarti bahwa paham deontologi tidak membolehkan menyelamatkan orang lain, namun usaha penyelamatan itu tidak dilakukan melalui perbuatan yang secara umum dianggap tidak baik. Sebaliknya, paham teleologi menekankan pada tujuan atau akibat yang dituju dari perbuatan itu. Jika tujuannya untuk kebaikan, maka perbuatan itu boleh dilakukan. Penganut paham ini sering disebut sebagai konsekuensialis. Jadi perbuatan mencuri, berbohong, atau membunuh diperbolehkan untuk menyelamatkan nyawa seseorang. Secara realita sangat jarang ditemukan orang yang mutlak menganut paham deontologi ataupun teleologi saja, lebih banyak yang mencampurkan kedua paham tersebut. Kedua paham besar etika itu sama-sama menghendaki agar apa pun yang dilakukan adalah untuk kebaikan dan kesejahteraan manusia. Para pakar biologi menggabungkan kedua paham itu dengan menyusun suatu etika baru yang disebut dengan istilah bioetik (etika biologi) (Daulay, 2012). Kebanyakan penguasa memilih jalan pintas, yaitu melarang kloning manusia. Sikap apriori ini tidak realistis karena semua teknologi selalu memiliki dua sisi, yaitu sisi baik dan jahat. Ibarat sebuah pisau yang dapat digunakan untuk kebaikan dan juga kejahatan (Mohamad, t.t). Untuk itu, ahli bioetika memiliki tanggung jawab untuk memastikan kategori-kategori yang tepat untuk digunakan dalam perdebatan kloning (Shuster, 2003).

Van Peursen dalam Semiawan, dkk., (1988) mengakui bahwa aplikasi penemuan ilmiah itu pada umumnya bergantung kepada suatu putusan politik. Artinya, seorang ilmuwan hanya dapat memberikan alternatif-alternatif pemecahan masalah berdasarkan hasil penelitian ilmiah. Van Melsen dalam Semiawan, dkk., (1988) juga menjelaskan bahwa ilmuwan harus memiliki kewajiban etis dan keinsyafan etis. Kewajiban etis untuk menyadari adanya ketegangan antara yang seharusnya ada dan yang pada kenyataannya ada, sedangkan keinsyafan etis tidak hanya menyangkut apa yang seharusnya ada, namun apa yang sebetulnya seharusnya ada seandainya kemungkinan-kemungkinan realitasnya berbeda dari keadaan yang nyata.

Tanggung jawab moral seorang ilmuwan merupakan refleksi dari kewajiban moral (moral imperative). Menurut interpretasi Kant, kewajiban moral erat kaitannya dengan moral law yang ekspresinya lebih sulit dijelaskan. Seorang ilmuwan harus memiliki kepekaan besar terhadap konsekuensi-konsekuensi etis terkait ilmunya, sebab dialah yang dapat mengikuti perkembanganperkembangan yang konkret dari dekat. Namun, tentu saja kualifikasi etis tak dapat diberikan kepada segala sesuatu, sebab pengertian yang secara etis baik selalu terdapat lebih implisit daripada eksplisit. Seorang ilmuwan sebenarnya tidak dapat berbuat banyak untuk mencegah penyalahgunaan hasil penemuan mereka, karena manusia cenderung untuk menciptakan dilema pada tiap hasil penemuannya, seperti menciptakan pedang yang bermata dua (Semiawan, dkk., 1988).

Terdapat dua kelompok ilmuwan dalam menghadapi ekses ilmu dan teknologi yang bersifat merusak, yaitu: 1) Kelompok yang menginginkan ilmu itu harus bersifat netral terhadap nilai, baik secara ontologis maupun aksiologis. Tugas ilmuwan adalah menemukan pengetahuan, dan selanjutnya terserah pihak lain dalam menggunakannya untuk tujuan yang baik atau buruk, dan 2) Kelompok yang berpendapat bahwa netralitas ilmu terhadap nilai terbatas pada metafisik keilmuan, sedangkan dalam penggunaan pengetahuan dan pemilihan obyek penelitian, maka kegiatan keilmuan harus berlandaskan asas-asas moral. Secara moral, ilmu harus ditujukan untuk kebaikan manusia tanpa merendahkan martabat atau mengubah hakikat kemanusiaan (Suriasumantri, 2010). Menurut Semiawan, dkk. (1988) ilmuwan Indonesia memiliki cara pandang yang dapat dijadikan landasan untuk bertindak, tidak sama dengan ilmuwan-ilmuwan dari berbagai negara. Daya kreatif seorang ilmuwan Indonesia tetap dituntut untuk menciptakan sesuatu di kemudian hari yang tidak bertentangan dengan cara pandang kita yang berdasarkan Pancasila.

Terkait dengan masalah teknologi yang mengakibatkan proses dehumanisasi, Suriasumantri (2010) berpendapat hal itu lebih merupakan masalah kebudayaan daripada masalah moral. Artinya, masyarakat yang harus menentukan teknologi mana saja yang akan atau tidak akan dipergunakan 
untuk mengantisipasi ekses teknologi yang negatif. Secara konsep, masyarakat harus menetapkan strategi pengembangan teknologinya agar sesuai dengan nilai-nilai budaya yang dijunjungnya. Pendapat ini diperkuat oleh Nabavizadeh, dkk. (2016) dalam artikelnya yang menyimpulkan bahwa metode yang tepat untuk mencegah penyalahgunaan teknologi kloning untuk mendapatkan manfaat ilegal dan melemahkan hak kekayaan intelektual bagi ilmuwan dan peneliti adalah membimbing dan mengendalikan teknologi kloning tersebut, karena melarang teknologi kloning tersebut tidak selalu berhasil. Upaya harus dilakukan untuk menciptakan sistem hukum-etika yang sesuai dan hukum komprehensif yang disepakati.

Berbeda dengan pendapat sebelumnya, The Council on Bioethics (2002) di Washington D.C. dalam ringkasan eksekutifnya bersepakat penuh menyatakan bahwa kloning reproduktif bukan hanya tidak aman, tapi juga tidak dapat diterima secara moral, dan seharusnya tidak dilakukan. Ada lima hal yang diidentifikasi terkait dengan kloning reproduktif, yaitu masalah identitas dan individualitas manusia hasil kloning, kekhawatiran akan komersialisasi dan industrialisasi terhadap manusia hasil kloning, prospek terhadap eugenika baru, masalah dalam hubungan keluarga, dan pengaruh terhadap masyarakat. Menurut Martin dalam Kusmaryanto (2008), eugenika adalah suatu teori yang berhubungan dengan peningkatan kualitas keturunan melalui pinsip-prinsip genetika. Selain itu, Kusmaryanto (2008) juga menyatakan bahwa dalam proses kloning manusia terdapat tindakan pembunuhan terencana yang disengaja. Sebagaimana dalam proses produksi suatu barang, ada kriteria kontrol kualitas yang harus dipenuhi untuk menjaga kualitas produk. Demikian juga halnya dalam proses kloning, hasil klon yang tidak sesuai dengan kriteria yang diharapkan akan disingkirkan (dibunuh). Day (2018) mengajukan sebuah pertanyaan tentang "apakah manusia harus dikloning atau tidak?" Pertanyaan ini tidak mudah untuk dijawab karena terdapat pihak-pihak yang pro dan kontra.

Dari pembahasan di atas penulis setuju dengan pandangan paham deontologi terhadap teknologi kloning manusia. Paham deontologi menekankan penilaian etis-tidaknya suatu perbuatan lebih kepada perbuatan itu sendiri, bahwa perbuatan yang dinyatakan terlarang secara umum (universal), apa pun alasannya tidak boleh dilakukan. Namun, dunia internasional belum sepakat bahwa perbuatan mengkloning manusia adalah terlarang. Adapun terhadap pandangan paham teleologi dalam kloning manusia, penulis tidak setuju. Paham teleologi lebih menilai pada tujuan atau akibat dari perbuatan itu, kalau tujuannya untuk kebaikan, maka perbuatan itu boleh dilakukan. Sebenarnya sulit untuk menentukan apakah tujuan ilmuwan melakukan kloning manusia itu semata-mata untuk pengembangan keilmuan atau ada tujuan-tujuan lain yang tidak dapat dibenarkan. Oleh karena itu, regulasi yang jelas dan ketat diperlukan dalam mengantisipasi dampak buruk dari perkembangan teknologi kloning, khususnya kloning manusia. Perumusan regulasi harus melibatkan banyak pihak seperti pakar bioteknologi, instansi pemerintah yang terkait, budayawan atau tokoh masyarakat, ulama yang paham figh Islam, pakar filsafat, akademisi, pihak industri, pakar hukum, dan pihak lain yang terkait secara langsung atau tidak langsung dengan teknologi kloning. Semua pihak ini berupaya menggali dan menelaah manfaat dan dampak negatif teknologi kloning manusia ditinjau dari berbagai aspek kehidupan manusia. Demikian juga halnya terhadap teknologi kloning terapeutik, perlu adanya regulasi yang jelas agar tidak ada tindakan semena-mena terhadap embrio manusia, meskipun tujuan kloning terapeutik itu bermanfaat bagi manusia. Selain itu perlu dikembangkan teknik perbanyakan stem cells skala besar untuk menjamin ketersediaannya bagi kepentingan penelitian lanjutan atau pengobatan pasien.

\section{PENUTUP}

Perbincangan tentang kloning manusia terus bergulir karena adanya berbagai opini. Isu yang sering dibahas tentang kloning manusia terkait dengan aspek etika atau moral. Dalam Filsafat IImu, etika merupakan prinsip yang medasari perilaku manusia, sehingga etika juga disebut dengan istilah moral. Sudut pandang deontologi menilai suatu perbuatan itu etis atau tidak lebih ditekankan kepada perbuatan itu sendiri, dan dunia internasional belum sepakat untuk melarang tindakan mengkloning manusia. Sementara itu, paham teleologi lebih menilai pada tujuan atau akibat yang dituju dari 
perbuatan itu. Ilmuwan yang menganut paham teleologi harus menyatakan secara tegas tujuannya melakukan penelitian kloning manusia dan harus bisa memprediksi akibat yang akan timbul dari penelitiannya tersebut. Pada akhirnya, secara etika seorang ilmuwan dituntut untuk menggunakan sains demi kesejahteraan manusia, bukan untuk merendahkan atau menghancurkan kehidupan manusia.

\section{UCAPAN TERIMAKASIH}

Penulis mengucapkan terima kasih kepada Harry Firman (Dosen Filsafat IImu) yang telah membaca dan memberikan saran terhadap artikel ini.

\section{DAFTAR PUSTAKA}

Campbell, N. A., \& Reece, J. B. (2010). Biologi (ed. ke-8, jilid 1). Jakarta : Penerbit Erlangga.

Creswell, J. W. (2012). Educational research: Planning, conducting, and evaluating quantitative and qualitative research $\left(4^{\text {th }} \mathrm{ed}\right)$. Boston : Pearson Education, Inc.

Daulay, S. (2012). Kloning manusia dalam perspektif etika dan agama. [Online]. Diakses dari http://salehdaulay.com/index.php/riset/item/131-kloning-manusia-dalam-perspektif-etika-dan-agama (Diakses pada tanggal 6 Desember 2018).

Day, L. (2018). Human cloning pros and cons: Should human cloning be legal? [Online]. Diakses dari https://www.kelseygroup.com/human-cloning-pros-and-cons/ (Diakses pada tanggal 6 Desember 2018).

Firman, H. (2016). Etika Sains (Makalah tidak dipublikasikan). Sekolah Pascasarjana Universitas Pendidikan Indonesia, Bandung.

Ihsan, A. F. (2010). Filsafat ilmu. Jakarta : Rineka Cipta.

Jalaluddin. (2013). Filsafat ilmu pengetahuan. Jakarta : RajaGrafindo Persada.

Kusmaryanto, C. B. (2008). A discourse to UNESCO: Human cloning an ethical approach. Yogyakarta : Dehonian Press.

Kusmaryanto, C. B. (2001). Problem etis kloning manusia. Jakarta : Grasindo.

Mohamad, K. (t.t.). Aspek bioetika dari kloning manusia. [Online]. Diakses dari http://tulisanterkini.com/artikel/biologi/1542-aspek-bioetika-dari-kloning-manusia.html. (Diakses pada tanggal 6 Desember 2018).

Nabavizadeh, S. L., Mehrabani, D., Vahedi, Z., \& Manafi, F. (2016). Cloning: A Review on Bioethics, Legal, Jurisprudence and Regenerative Issues in Iran. World journal of plastic surgery, 5(3), 213-225.

Semiawan, C. R. (2005). Panorama filsafat ilmu: Landasan perkembangan ilmu sepanjang zaman. Bandung : Teraju.

Semiawan, C. R., Putrawan, I. M., \& Setiawan, T. I. (1988). Dimensi kreatif dalam filsafat ilmu. Bandung : Remadja Karya.

Shuster, E. (2003). Human cloning: Category, dignity, and the role of bioethics. Bioethics $17(5-6): 517-525$. https://doi.org/10.1111/1467-8519.00365

Sudjana. (2015). Aspek hukum penggunaan deoxyribonucleic acid (DNA) pada proses kloning embrio manusia. Jurnal IImu Kesehatan Masyarakat, 6(3):145-159.

Sugiyono. (2016). Metode penelitian pendidikan: Pendekatan kuantitatif, kualitatif, dan R\&D. Bandung : Alfabeta.

Suhartono, S. (2008). Filsafat ilmu pengetahuan: Persoalan eksistensi dan hakikat ilmu pengetahuan. Jogjakarta : Ar-Ruzz Media.

Suriasumantri, J. S. (2010). Filsafat ilmu: Sebuah pengantar populer. Jakarta : Pustaka Sinar Harapan. 
Susanto, A. (2014). Filsafat ilmu: Suatu kajian dalam dimensi ontologis, epistemologis, dan aksiologis. Jakarta : Bumi Aksara.

The Council on Bioethics. (2002). Human cloning and human dignity: An ethical inquiry. [Online]. Diakses dari https://bioethicsarchive.georgetown.edu/pcbe/reports/cloningreport/execsummary.html (Diakses pada tanggal 6 Desember 2018).

Widayanti, H., \& Krishnayanti, I. N. (2003). Bioteknologi: Imperialisme modal \& kejahatan globalisasi. Yogyakarta : INSIST Press. 